\title{
RESULTS OF EXPERIMENTAL RESEARCH OF CONICAL ROTARY LOOSENER IN SOIL CANAL
}

\author{
Ilshat Mukhametshin ${ }^{1}$, Ayrat Valiev ${ }^{1}$, Farzutdin Mukhamadyarov ${ }^{2}$, Marat Kalimullin ${ }^{1}$, Fanis Yarullin ${ }^{1}$ \\ ${ }^{1}$ Kazan State Agrarian University, Russia; ${ }^{2}$ Vyatka State Agricultural Academy, Russia \\ ilshat858@gmail.com, ayratvaliev@mail.ru,marat-kmn@yandex.ru, fanis4444@mail.ru
}

\begin{abstract}
The article presents the results of experimental research of a conical rotary loosener for deep soil tillage. The loosener is a screw rotary conical tool mounted on a rack, with the possibility of rotation around its own axis from the reaction of the soil. Experimental research to assess the traction resistance of the loosener and to determine the dependency of the number of its revolutions per 1 meter of the traveled distance on the design parameters and the speed of movement were carried out in the soil canal of the Kazan State Agrarian University in accordance with the developed methodology. The influence of the number of turns of the loosener $n$, the rear cutting angle $\varepsilon$, the speed of movement $v$ and the hardness of the soil $\mathrm{H}$ on the traction resistance and the number of revolutions per 1 meter of the traveled distance of the loosener were studied. The soil in the soil canal was gray forest soil with a medium loamy texture. The values of soil density at the level of $1500 \mathrm{~kg} \cdot \mathrm{m}^{-3}$ with its moisture content of 17 $18 \%$, and the hardness varied in the range of 1.8-2.35 MPa. As a result of the calculations, regression equations were obtained for the traction resistance of the loosener and for the number of revolutions per meter of distance traveled. They were tested for adequacy according to the $F$-Fisher criterion. As a result of the research, the rational value of the number of turns $n=0.33$ was established, the rear cutting angle of the loosener $\varepsilon=4-5^{\circ}$, the travel speed $v=2.5 \mathrm{~m} \cdot \mathrm{s}^{-1}$.
\end{abstract}

Keywords: tillage, conical rotary loosener, design parameters, traction resistance, hardpan.

\section{Introduction}

The nature of the processes occurring in the soil under the influence of the working body depends on its geometric parameters, operating modes and physical and mechanical properties of the soil. The shape of the working body mainly determines the quality of tillage and its energy consumption [1-6]. Academician V.P. Goryachkin, developing the theoretical foundations of tillage machines, paid attention to the shape of the working body in the first place. He supposed that the screw is the working part of the tillage tool [6]. Since passive working bodies, soil cultivators in particular, due to the formation of a dragging core in front of them, have a large traction resistance and energy consumption, and are also less effective in comparison with rotary ones [7-12], a promising direction in the development of tillage machines is the development of a rotary working bodies of the screw type. You can get acquainted with a similar type of working bodies for soil cultivation in [13], tests carried out by the authors of the work, using an innovative cultivator with a spiral rotor, showed positive results. Based on these studies, our work also revealed its relevance.

\section{Materials and methods}

The team of authors of the Kazan State Agrarian University has developed a working body of the tillage unit, which is a cone rotary reactive ripper. To substantiate its design and setting parameters, laboratory studies of the interaction of the working surface with the soil were carried out, for which the working bodies of the screw type were made with the number of turns $0.2 ; 0.4 ; 0.6$ (Fig. 1 "a" and "b") and paddle type with two and three blades (Fig. 1 "c" and "d").

To register the traction resistance of the loosener, strain gauge equipment was used. KF5P1-15100-B-12 strain gauges were used as converters of mechanical values into electrical ones. They were glued to the working part of the strain gauge rack 1 (Fig. 2, a). The fastening of the conical rotary loosener on the rack (Fig. 2, b) was carried out using a special bracket with the ability to adjust the rear cutting angle in the range $\varepsilon=3^{\circ}$ to $7^{\circ}$.

A reed switch was installed on the same bracket, with the help of which the number of revolutions of the cultivator in the soil was measured in a circuit with an MES-66 electromagnetic pulse counter. The frequency of rotation was calculated by dividing the number of its revolutions by the time it took to pass the test section. The magnetic flux was directed to the reed switch from two magnets attached to a brass spacer mounted at the rear end of the ripper rotation axis. 
a)

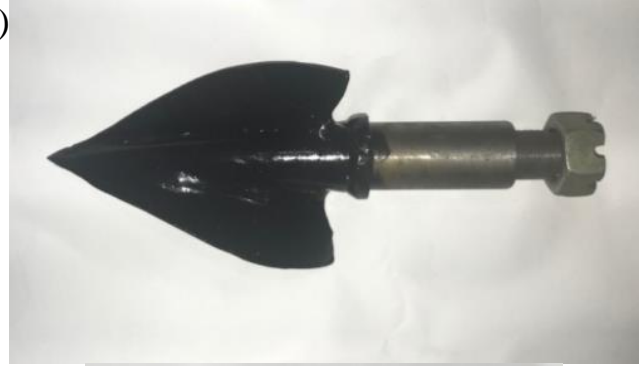

c)

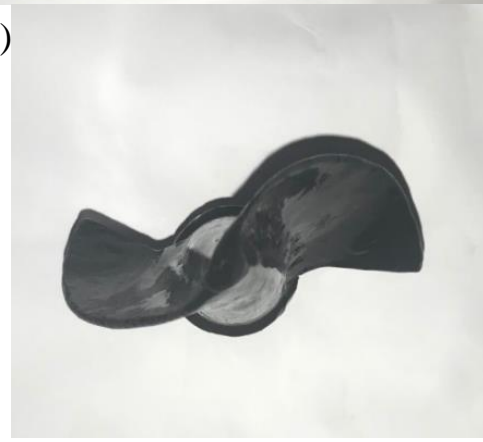

b)

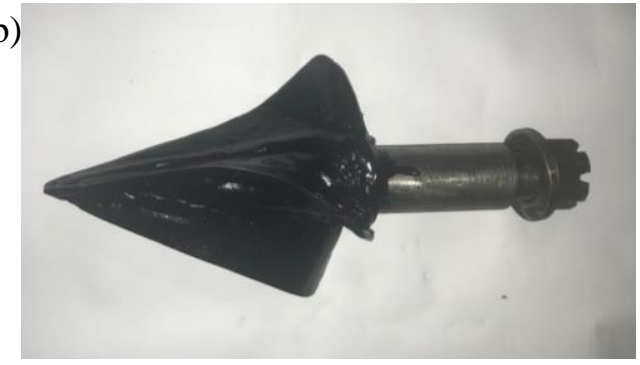

d)

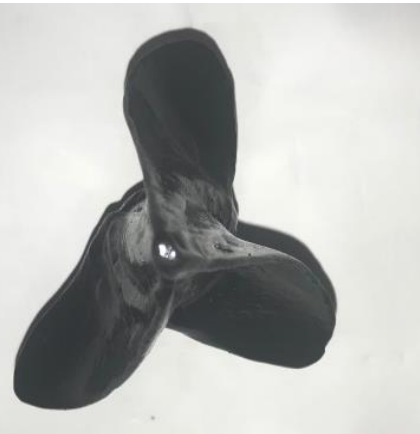

Fig. 1. Working body of the conical rotary loosener

a)

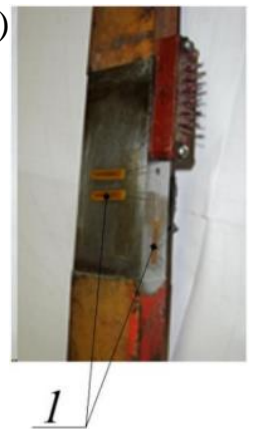

b)

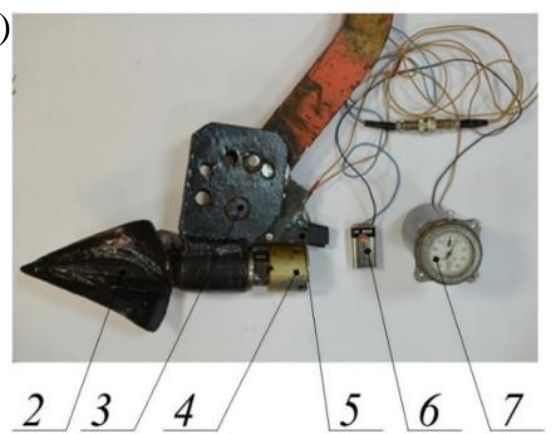

Fig. 2. Strain gauge rack (a) with a device for measuring the number of revolutions of the loosener (b): 1 - strain gauges; 2 - conical rotary loosener; 3 - bracket with the ability to adjust angle ; 4 - brass spacer with magnets; 5 - reed switch; 6 - power supply of the electromagnetic pulse counter; 7 - electromagnetic pulse counter MES-66

Power supply of the strain gauge bridge (Fig. 3) and collection of information from its diagonals was carried out using IP-264 data collection station 4 with an MC-5 coordination module. The strain gauge bridges were calibrated together with the entire measuring system according to the method according to IP-264 operations manual. The experimental unit (Fig. 3) is designed as follows. The strainer 1 with a conical rotary loosener is installed on the cart 5 by means of a device for adjusting the depth of soil cultivation. The cart moves along the soil canal along the rails due to the drive station, which consists of an electric motor, gearbox, drum and a cable. The change in the speed of movement of the cart is made by adjusting the speed of the electric motor using a frequency converter.

Factors selected for the active-passive experiment were.

1. The number of turns $0.2 ; 0.4 ; 0.6$ of a conical loosener $\left(X_{I}\right)$.

2. Rear cutting edge angle $3^{\circ}, 5^{\circ}, 7^{\circ}\left(X_{2}\right)$.

3. Loosener forward speed $2.0 ; 2.5 ; 3.0 \mathrm{~m} \cdot \mathrm{s}^{-1}\left(X_{3}\right)$.

4. Soil hardness $\left(X_{4}\right)$.

They are all independent of each other. The first three factors are controllable and manageable. They characterize the design and technological parameters. The fourth is measurable, but not controllable. It characterizes the hardness of the soil, determined immediately before each experiment.

Optimization criteria were selected. 
1. Traction resistance of the looserner $\mathrm{F}_{\mathrm{th}}, \mathrm{N} .\left(Y_{l}\right)$.

2. Number of revolutions per $1 \mathrm{~m}$ of distance traveled $\left(Y_{2}\right)$.

In connection with the above, an experiment plan (Table 1) was drawn up. The values of the factors were entered into the matrix in coded form.

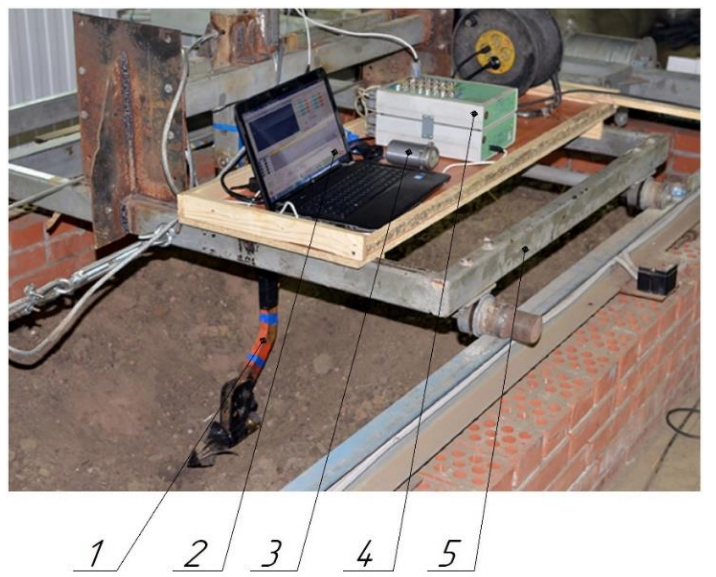

Fig. 3. Experimental unit: 1 - strain gauge rack; 2 - PC; 3 - MES-66;

4 - data collection station IP-264 with MS-5; 5 - cart

Matrix for planning the experiment in the soil canal

\begin{tabular}{|c|c|c|c|c|c|c|}
\hline \multirow[b]{2}{*}{ Experiment } & \multicolumn{4}{|c|}{ Factors } & \multicolumn{2}{|c|}{ Optimization criteria } \\
\hline & $\begin{array}{c}X_{I} \\
\text { number } \\
\text { of turns, } \\
n\end{array}$ & $\begin{array}{c}X_{2} \\
\text { rear cutting } \\
\text { edge anlge of } \\
\text { the working } \\
\text { body, } \varepsilon^{\circ}\end{array}$ & $\begin{array}{c}X_{3} \\
\text { speed } \\
v, \mathrm{~m} \cdot \mathrm{s}^{-1}\end{array}$ & $\begin{array}{c}X_{4} \\
\text { soil } \\
\text { hardness, } \\
\mathbf{k P a}\end{array}$ & $\begin{array}{c}Y_{1} \\
\text { traction } \\
\text { resistance, } \\
\mathrm{N}\end{array}$ & $\begin{array}{c}Y_{2} \\
\text { number of } \\
\text { rotations per } \\
1 \mathrm{~m} \text { of } \\
\text { distance } \\
\end{array}$ \\
\hline $\begin{array}{c}\text { Lower level } \\
(-)\end{array}$ & 0.2 & $3^{\circ}$ & 2.0 & \multirow{3}{*}{ - } & \multirow{3}{*}{ - } & \multirow{3}{*}{ 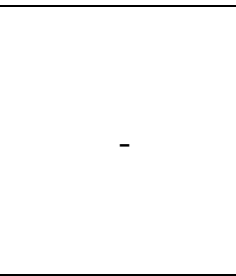 } \\
\hline $\begin{array}{c}\text { Main level } \\
(0)\end{array}$ & 0.4 & $5^{\circ}$ & 2.5 & & & \\
\hline $\begin{array}{c}\text { Higher level } \\
(+)\end{array}$ & 0.6 & $7^{\circ}$ & 3.0 & & & \\
\hline 1 & + & + & 0 & $X_{4-1}$ & - & - \\
\hline .. & $\ldots$ & $\ldots$ & $\ldots$ & ... & - & - \\
\hline 27 & 0 & 0 & 0 & $X_{4-27}$ & - & - \\
\hline
\end{tabular}

These studies were carried out in accordance with the methodology developed at the Kazan State Agrarian University. The research results of the working bodies of tillage tools are presented in the works [14].

\section{Results and discussion}

The data obtained as a result of the experimental studies in the soil canal on the effect of the number of turns of the loosener, the rear cutting edge of the angle, the speed of movement and soil hardness on the traction resistance and the number of revolutions per 1 meter of the cultivated path of the loosener were processed using Statistica 64 software.

As a result of calculations, the following regression equations were obtained, tested for adequacy according to the F-Fisher criterion (probability $p=0.95$ ): for the traction resistance of the loosener:

$$
\begin{aligned}
& Y_{1}=1764.71+1182.33 X_{1}+80.92 X_{2}+84.41 X_{3}+87.14 X_{4}+1036.32 X_{1}^{2}+35.87 X_{1} X_{2}+90.34 X_{1} X_{3}- \\
& -26.25 X_{1} X_{4}+33.66 X_{2}{ }^{2}+26.89 X_{2} X_{3}+39.88 X_{2} X_{4}+56.25 X_{3}{ }^{2}-50.28 X_{3} X_{4}-23.64 X_{4}{ }^{2} .
\end{aligned}
$$

For the number of revolutions per 1 meter of distance: 


$$
\begin{aligned}
& Y_{2}=2.156+1,216 X_{1}-0.101 X_{2}-0.021 X_{3}+0.167 X_{4}+0.463 X_{1}^{2}-0.027 X_{1} X_{2}+0.0525 X_{1} X_{3}- \\
& -0.063 X_{2}^{2}-0.041 X_{2} X_{3}-0.062 X_{3}^{2}+0.036 X_{3} X_{4}+0.016 X_{4}{ }^{2} .
\end{aligned}
$$

The graphic interpretation of the model (1) is shown in Fig. 4. Analysis of the mathematical model (1) at fixed values of the average level of the loosener forward speed $\left(X_{3}\right)$ and soil hardness $\left(X_{4}\right)$ shows that with an increase in the number of the loosener's turns $\left(X_{l}\right)$, the traction resistance for its movement increases. This is quite logical, since with an increase in the number of turns the normal component to the working surface of the conical rotary loosener will approach its center line, providing maximum resistance.

With an increase in the rear cutting edge angle of the working body $\left(X_{2}\right)$, the traction resistance also increases, but less intensively. With the number of turns equal to 0.33 and the rear cutting edge angle of the working body at $5^{\circ}$, the traction resistance of the working body is minimal and equal to $1500 \mathrm{~N}$.
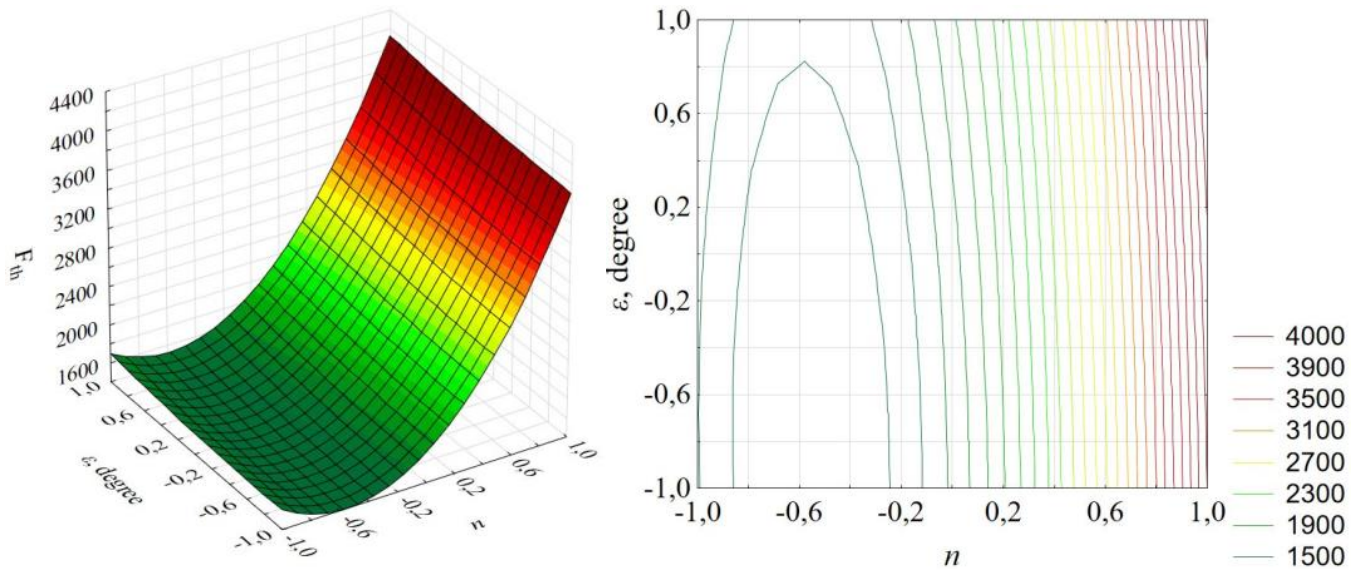

Fig. 4. Dependency of traction resistance of the working body $F_{t h}\left(Y_{I}\right)$ on the number of turns on its cone $n\left(X_{I}\right)$ and on the rear cutting edge angle of the working body $\varepsilon\left(X_{2}\right)$

A graphical representation of the model (2) is shown in Fig. 5. Analysis of the mathematical model (2) at fixed values of the average level of the ripper movement speed $\left(X_{3}\right)$ and soil hardness $\left(X_{4}\right)$ shows that with an increase in the number of ripper turns $\left(X_{I}\right)$, the number of revolutions per 1 meter increases. And with an increase in the rear cutting edge angle of the loosener $\left(X_{2}\right)$, the number of revolutions, on the contrary, decreases. Moreover, the factor of the number of loosener turns $\left(X_{l}\right)$ influences the optimization criterion to a greater extent in comparison with the factor of the rear cutting edge angle $\left(X_{2}\right)$.
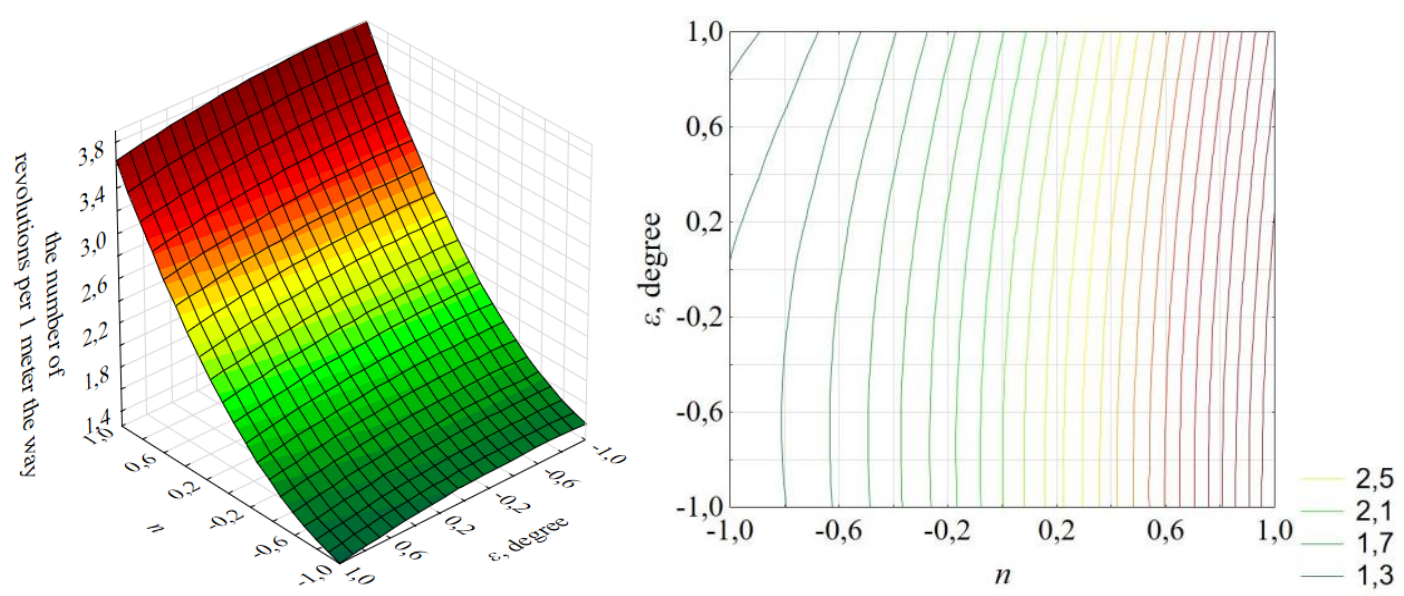

Fig. 5. Dependence of the number of revolutions of the working body per 1 meter of the traveled distance $\left(Y_{2}\right)$ on the number of turns on its cone $n\left(X_{1}\right)$, rear cutting edge of the working body $\varepsilon\left(X_{2}\right)$

In a similar way, the influence of other factors and their combinations on the optimization criteria $Y_{1}$ and $Y_{2}$ was analyzed. 


\section{Conslusions}

The rational value of the traction resistance of the working body at the level of $2300 \mathrm{~N} \ldots 2500 \mathrm{~N}$ is achieved over the entire range of soil hardness $(2.2 \mathrm{MPa} \ldots 2.75 \mathrm{MPa})$ with the following values of the working body parameters: the number of turns $\mathrm{n}=0.33$, the rear cutting edge angle of the working body is $4^{\circ} \ldots 5^{\circ}$; the forward speed $2 \mathrm{~m} \cdot \mathrm{s}^{-1} \ldots 2.5 \mathrm{~m} \cdot \mathrm{s}^{-1}$. In this case, the number of revolutions per one meter of the traveled distance of the working body is 2.12 .

\section{References}

[1] Mudarisov S.G., Gabitov I.I., Lobachevsky Y.P., Mazi tov N.K., Rakhimov R.S., Khamaletdinov R.R., Rakhimov I.R., Farkhutdinov I.M., Mukhametdinov A.M., Gareev R.T. Modeling the technological process of tillage. Soil \& Tillage Research. 2019. Vol. pp. 190. 70-77.

[2] Акимов А.П. Проблема энергетических затрат при основной обработке почвы (The problem of energy costs in the main tillage)/А.П. Акимов, В.И. Медведев, В.П. Мазяров // Вестник Чувашской государственной сельскохозяйственной академии. 2018. №4 (7). - pp. 78-82. (In Russian).

[3] Galiev I., Khafizov K., Khusainov R., Faskhutdinov M. Ensuring possibility of functioning of tractors in agricultural production taking into account residual resources of their units and systems //19-th International Scientific Conference Engineering for rural development Proceedings, Volume 18 May 22-24, 2020, pp. 48-53.

[4] Khafizov C., Khafizov R., Nurmiev A., Galiev I. Optimization of main parameters of tractor and unit for plowing soil, taking into account their influence on yield of grain crops //19-th International Scientific Conference Engineering for rural development Proceedings, Volume 18 May 22-24, 2020, pp. 585-590.

[5] Горячкин В. П. Собрание сочинений. В 3 т. (Collected works. In 3 t.) - 2-е изд. - М.: Колос, 1968. - T. 1. - 1968. - 720 c. (In Russian).

[6] Valiev A., Mukhametshin I., Muhamadyarov F., Kalimullin M., Yarullin F. Kinematic analysis of conical rotary subsoil loosener for tillage/19-th International Scientific Conference Engineering for Rural Development Proceedings. Latvia University of Agriculture. Faculty of Engineering. 19, pp. 1946-1952.

[7] Valiev A., Mukhametshin I., Muhamadyarov F., Yarullin F., Pikmullin G. Theoretical substantiation of parameters of rotary subsoil loosener/18-th International Scientific Conference Engineering for Rural Development Proceedings. Latvia University of Agriculture. Faculty of Engineering. 18, 312-318 (2019).

[8] Ahmadi I. A power estimator for an integrated active-passive tillage machine using the laws of classical mechanics/I. Ahmadi // Soil \& Tillage Research, 171, 2017. pp. 1-8.

[9] Deep diggers give a high lift to yields // Farmers Weekly. - 1991. - Vol. 115, № 18. 42 p.

[10] CIGR Handbook of Agricultural Engineering. Ed. Bill A. Stout. Texas A\&M University. Published by ASAE, 1999. - $660 \mathrm{p}$.

[11] Schneider F., Don A., Hennings I., Schmittmann O., Seidel S.J. The effect of deep tillage on crop yield - What do we really know? Soil \& Tillage Research. 2017. Vol. 174. pp. 193-204.

[12] Destain M.-F., Houmy K. Effects of design and kinematic parameters of rotary cultivators on soil structure. Soil \& Tillage Research. 1990. Vol. 17, Issues 3-4, pp. 291-301

[13] Fouda O.A. A Spiral Rotor Tiller for Tillage Heavy and Dry Clay Soil. J. Soil Sci. and Agric. Eng., Mansoura Univ., 2016, Vol. 7 (12), pp. 929-936.

[14]Валиев, А.Р. Результаты экспериментальных исследований ротационного конического рабочего органа в почвенном канале (Results of experimental studies of a rotary conical working body in a soil channel)/A.Р. Валиев. Р.И. Ибятов, Р.Р. Шириязданов, Ф.Ф. Яруллин Вестник Казанского ГАУ. - 2014. - No. 3 (33). - pp.78-85. (In Russian). 